\title{
Arsenic deposition in tissues of the European hare (Lepus europaeus)
}

\author{
Karel Bukovjan, Zdeňka Wittlingerová, Karel Kutlvašr \\ Czech University of Life Sciences Prague, Faculty of Environmental Sciences, \\ Prague, Czech Republic \\ Received June 11, 2015 \\ Accepted May 2, 2016
}

\begin{abstract}
The work deals with arsenic deposition in individual biological matrices of the European hare (Lepus europaeus Pall.). The aim of this work was to evaluate the arsenic deposition in biological matrices of adult hares distributed by sex, and to highlight the need for monitoring this element in the natural environment. Determination of arsenic concentration was carried out on 11 biomarkers in 105 adult hares from variously loaded areas of the Czech Republic. Individual matrices include the liver, kidneys, brain, adipose tissue, reproductive organs, bone, fur, faeces, lungs, skeletal muscle and the heart. Inductively coupled plasma mass spectrometry was employed as a method to detect arsenic concentrations in the tissues. Arsenic deposition in the monitored biological matrices of adult animals showed no significant differences between sexes. The ratio of arsenic concentration in the skeletal muscle as compared with concentration in other tissues was 1:2.96 in the liver, followed by 1:4.35 in kidneys, 1:1.07 in the heart, 1:2.73 in lungs, 1:3.12 in ovaries, 1:3.30 in testicles, 1:5.90 in bones, 1:114.68 in fur, and 1:60.05 in faeces. Deposition of this element in matrices has a similar character and only differs in concentrations.
\end{abstract}

Wild game, biomarkers, xenobiotics, contamination

Arsenic is considered a high-risk chemical element which is not only built up uncontrollably over a long period in the natural environment, in wildlife, farm and domestic animals but also in the human population. It is a pollutant with strong carcinogenic, mutagenic and cytotoxic effects to higher organisms (Germolec et al. 1997; Yanamaka et al. 1997; Goering et al. 1999; Mass et al. 2001; Hughes 2002; Dopp et al. 2004).

The European hare (Lepus europaeus Pall.) is widespread throughout practically the whole of Europe except northern Scandinavia, Iceland, and Ireland. Hare populations are important components of cultural landscape ecosystems. The population dynamics depends mainly on the interrelations with the environment. Long-term monitoring of these issues point to a certain periodicity in the multitudinousness of individual populations.

Due to its way of life, relatively small territory, short generation interval and processed reference values of haematological and biochemical indicators, this species can be used in environmental monitoring of the anthropogenic loads by foreign substances in the environment, as well as in studying chromosomal aberrations and cancer incidence in these populations.

The aim of this work was to evaluate the arsenic deposition in biological matrices of adult hares distributed by sex, and to highlight the need for monitoring this element in the natural environment.

The monitoring of arsenic in wildlife in the Czech Republic has been somewhat neglected compared to other foreign substances. This element has practically remained unmonitored in game in recent years despite the fact that game is commonly consumed by people.

The biological screening and monitoring of these xenobiotics in the body of game is of high importance from the hygienic point of view. It is primarily used to protect the food chain of the human population. Based on this screening, similar physiological and

Address for correspondence:

Zdeňka Wittlingerová

Faculty of Environmental Sciences

Czech University of Life Sciences Prague

Kamýcká 129, Praha 6 - Suchdol, 165 21, Czech Republic

Phone: +420602 185857

E-mail: wittlingerova@fzp.czu.cz

http://actavet.vfu.cz/ 
pathological reactions in humans, livestock and wildlife allow determination of health standards for assessing food and contamination of individual components of the natural environment (Páv et al. 1986; Bukovjan and Wittlingerová 1997).

Massanyi et al. (2003) also dealt with the monitoring of chemical element loads in the European hare. The results of arsenic contamination in hares are known in Croatia (Skrivanko et al. 2008). The results show a different level of contamination in game within managed ecosystems.

Chemical elements are monitored not only in the game meat and organs used for human consumption, but in recent years they were also detected in various animal neoplasms. We have encountered this phenomenon in benign and malignant neoplasms in wildlife. Some of these observations were already reported by others and also by our research group (Flux 1965; Karpenko and Bukovjan 1996; Hoffmann and Morl 1985; Hofe et al. 2004; Bukovjan et al. 2011; Kutlvašr et al. 2014).

As proven before, tumours diagnosed in both human and veterinary pathology are usually identical (Bukovjan and Karpenko 1990; 1995) and the international ICD-O classification of neoplasms may be applied to find a common platform and terminology. Selected chemical elements including arsenic were also monitored in the tumours along with the study of these elements in various non-neoplastic tissues (Bukovjan and Karpenko 1996; Bukovjan et al. 2014).

\section{Materials and Methods}

The subject of this work was to monitor the presence of arsenic in 105 adult hares older than one year, of which 51 were males $(48.57 \%)$ and 54 were females $(51.43 \%)$. The animals came from differently loaded ecosystems of the Hodonín region (42), Litoměřice - Mělník region (32) and Pardubice - Hradec Králové region (31). These groups are well balanced and therefore well statistically interpretable. The tissues were sampled randomly from the brain, subcutaneous adipose tissue, skeletal muscle, myocardium, lungs, liver, kidneys, ovaries, testicles, and faeces. For sampling bones, the femur was used from all tested animals. Fur was also investigated, and it was taken and analysed as a mix from three sampling areas - from the second half of the back and from the left and right shoulder blade region. The samples investigated in this study were collected between the years 2009 and 2013.

The samples were kept frozen at $-21^{\circ} \mathrm{C}$ until analysis. The examination itself was performed after homogenisation and microwave pressure digestion (EN 13805:2014) of the sample with the aid of optical emission spectrometry (EN 15763:2009) with inductively coupled plasma mass spectrometry ICP/MS (Agilent, model: $7500 \mathrm{ce}$ ). Calibration was performed using a standard ICP-MS multi-element calibration standard solution VI (Merck). The method parameters were as follows - the limit of detection of arsenic is $0.003 \mathrm{mg} \cdot \mathrm{kg}^{-1}$, the limit of quantification was $0.005 \mathrm{mg} \cdot \mathrm{kg}^{-1}$.

The data obtained from animals were tested for normality and homogeneity of distribution. Subsequently, one-factorial ANOVA test was performed to detect the difference in concentration in different tissues $(P=0.05$, $\mathrm{F}=51.42)$. Post hoc Fisher LSD test was then performed to detect differences among individual types of matrices.

\section{Results}

Determination of arsenic concentrations in different biological matrices was performed in both sexes of the adult European hare. The initial results of the measured values were statistically processed and summarised in Table 1 (female hares) and Table 2 (male hares). The overall results of the hares regardless of the sex distribution are summarised in Table 3. The ratio between the values of arsenic in various matrices, where the concentration of the element in the mass of muscle tissue is equal to 1.00 , is indicated in Table 4, and it refers to the entire cohort of examined hares.

Determination of arsenic in the liver of the European hare did not reveal any significant differences in relation to sex. In male hares, the mean concentration of this element was $0.0192 \pm 0.021 \mathrm{mg} \cdot \mathrm{kg}^{-1}$, and in female hares it was $0.0187 \pm 0.020 \mathrm{mg} \cdot \mathrm{kg}^{-1}$. Maximum concentrations were also comparable $\left(0.097 \mathrm{mg} \cdot \mathrm{kg}^{-1}\right.$ in males and $0.096 \mathrm{mg} \cdot \mathrm{kg}^{-1}$ in females) (Tables 1 and 2). 

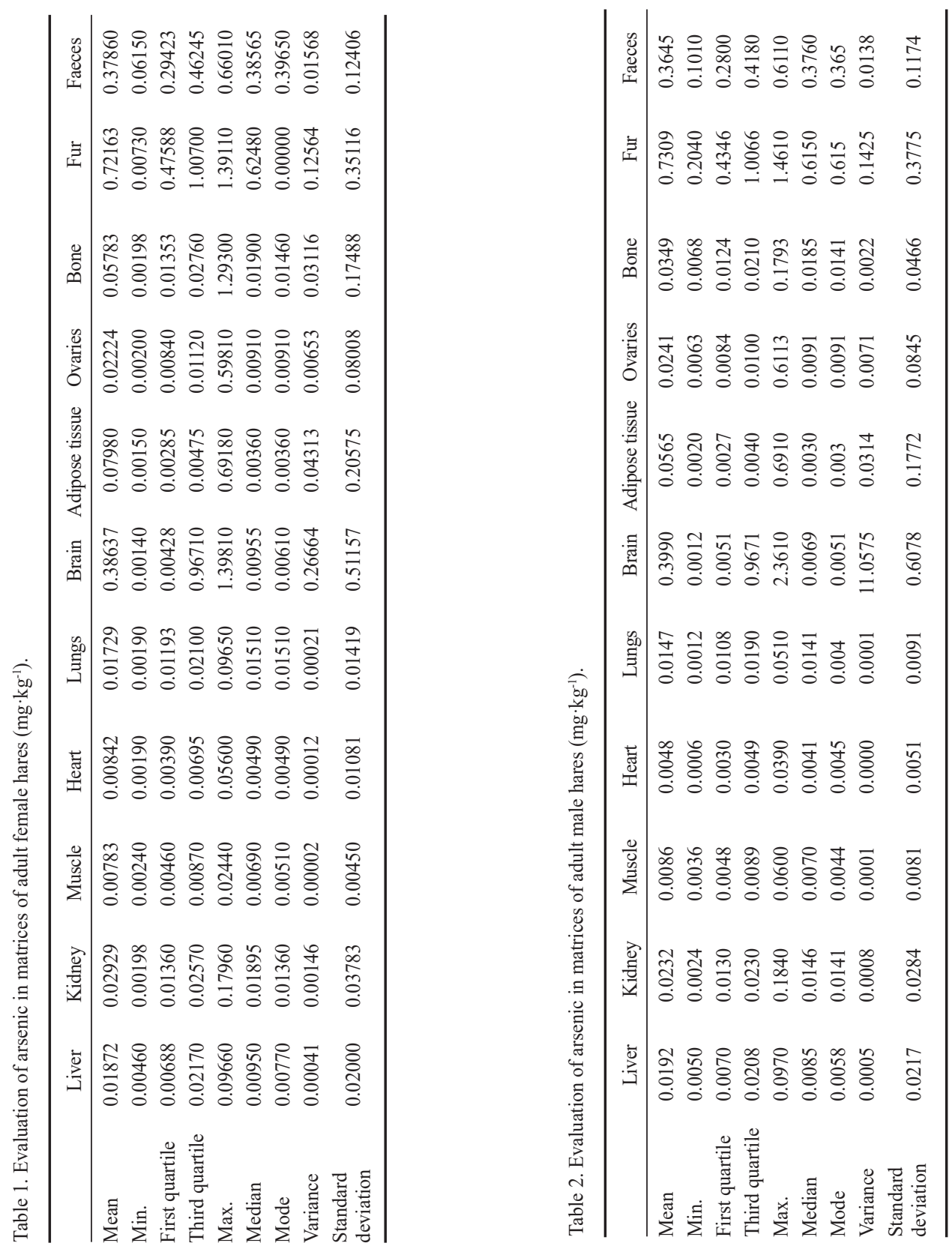

The values of arsenic in the kidneys are fully comparable in both sexes, and they show no significant differences. In the kidneys of both sexes, higher arsenic concentrations compared to the liver were observed. Detailed statistics are shown in Tables 1, 2, and 3.

The amount of arsenic in the skeletal muscle of hares was minimally different between the sexes. In males, the highest recorded concentration of arsenic was approximately 

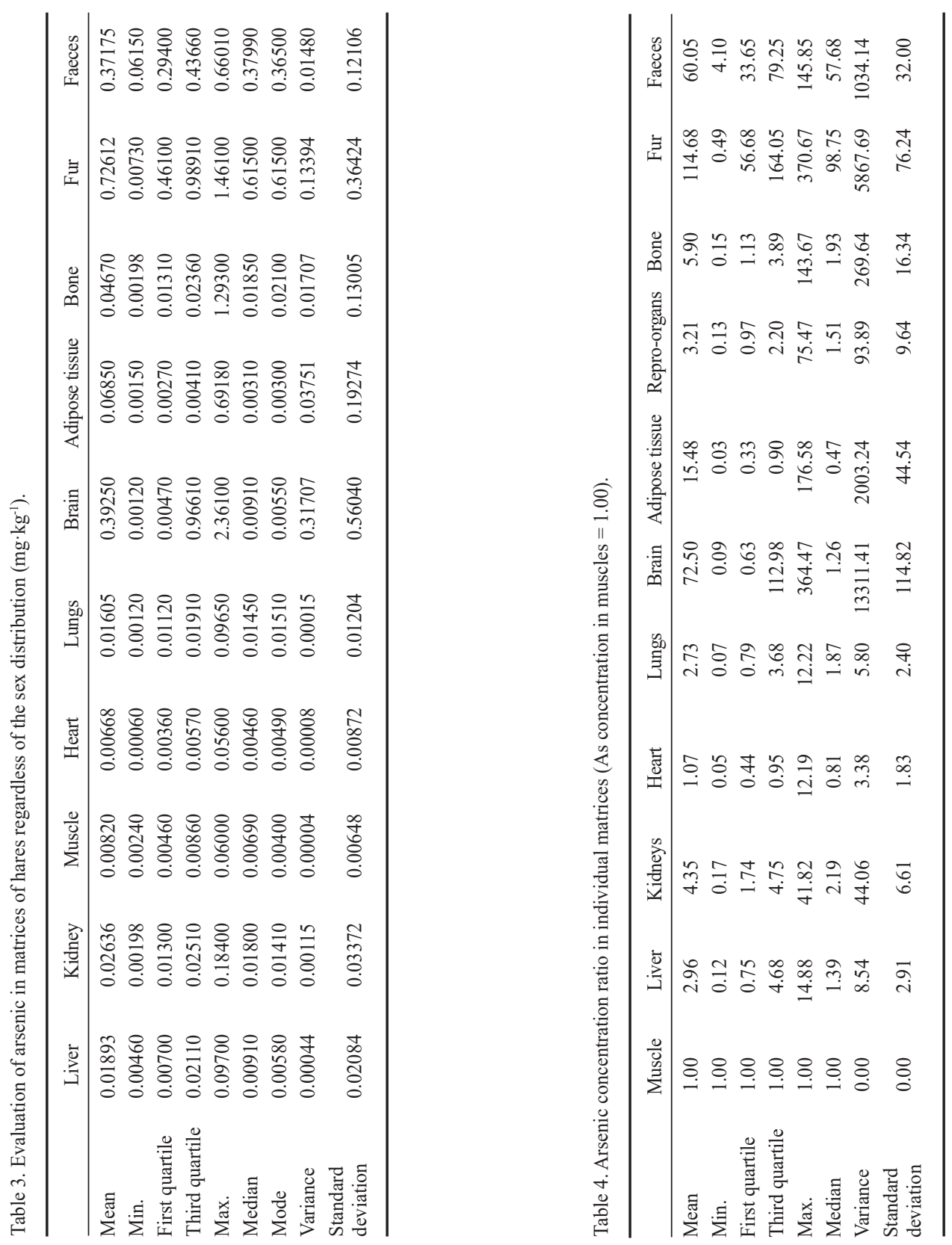

$\times 3$ higher than in female animals $\left(0.0600 \mathrm{mg} \cdot \mathrm{kg}^{-1}\right.$ in males and $0.0244 \mathrm{mg} \cdot \mathrm{kg}^{-1}$ in females $)$. The mean value of the element in the muscle tissue was $0.0086 \pm 0.008 \mathrm{mg} \cdot \mathrm{kg}^{-1}$ in male hares and $0.0078 \pm 0.0045 \mathrm{mg} \cdot \mathrm{kg}^{-1}$ in female hares.

The mean concentration of arsenic in the myocardium differs between the two sexes. It was twice as high in females $\left(0.0084 \pm 0.0108 \mathrm{mg} \cdot \mathrm{kg}^{-1}\right)$ as compared to males 
$\left(0.0048 \pm 0.0051 \mathrm{mg} \cdot \mathrm{kg}^{-1}\right)$. The results between the monitored groups at a specified level of significance were not conclusive $(P=0.05)$. The comparison of arsenic deposition between the skeletal muscle and the myocardium did not reveal any significant differences. Compared to other monitored biomarkers, both skeletal muscle and myocardium may be regarded as biological matrices least loaded by the monitored element.

When evaluating the amount of arsenic in the lungs, virtually identical concentrations were found for both sexes $\left(0.0147 \pm 0.0091 \mathrm{mg} \cdot \mathrm{kg}^{-1}\right.$ in males and $0.0173 \pm 0.014 \mathrm{mg} \cdot \mathrm{kg}^{-1}$ in females), with a higher maximum concentration of the element found in females compared to males $\left(0.0965 \mathrm{mg} \cdot \mathrm{kg}^{-1}\right.$ vs. $\left.0.051 \mathrm{mg} \cdot \mathrm{kg}^{-1}\right)$.

Compared to other tissues (except for fur and faeces), higher concentrations of the element were detected in the central nervous system. The mean concentration of arsenic in females was $0.386 \pm 0.511 \mathrm{mg} \cdot \mathrm{kg}^{-1}$ and it was comparable to the findings in males $\left(0.399 \pm 0.607 \mathrm{mg} \cdot \mathrm{kg}^{-1}\right)$. Relatively high values, above $1.00 \mathrm{mg} \cdot \mathrm{kg}^{-1}$, were recorded in 11 male individuals compared to 9 female individuals exceeding this level. The majority of individuals with higher levels of arsenic in the brain came from the Pardubice - Hradec Králové agglomeration. Positive correlation $(\mathrm{r}=0.240)$ was recorded between the kidneys and the brain.

Arsenic concentrations in the adipose tissue were relatively high in comparison with, for example, parenchymatous organs. In females, the concentration was lower compared to males, but the results were not significantly different between the sexes. Mutual correlations were noted between muscles and fur $(\mathrm{r}=0.300)$, and also between adipose tissue and muscles $(\mathrm{r}=0.160)$.

Arsenic concentration in the monitored European hare was $0.0241 \pm 0.084 \mathrm{mg} \cdot \mathrm{kg}^{-1}$ in the testes and $0.0222 \pm 0.080 \mathrm{mg} \cdot \mathrm{kg}^{-1}$ in the ovaries. These were minimally differing concentrations with a comparable variance within the groups.

In the bone tissue of the individual hares, the concentrations of arsenic were relatively higher compared to the liver, kidneys, myocardium, and skeletal muscle. A higher mean concentration was observed in females than in males (Tables 1, 2). However, in mutual comparison of values, no significant differences were identified.

The highest arsenic concentrations were detected in fur. Comparable mean concentration of the element in fur was detected in both males and females (Table 1 and 2). There was no significant difference between the groups.

The concentration of arsenic in the faeces of the European hare showed minimal variance of the measured values in the groups. The mean arsenic concentration in faeces of the males was approximately half of the values detected in fur. Practically the same was observed in the females (Table 1 and 2). The arsenic content in the faeces shows that this element is excreted from the body in a natural way and the quantity is continuously decreasing in conditions where animals are not exposed to constant contamination.

\section{Discussion}

Arsenic is considered a significant environmental pollutant that in general has serious toxic effects on animals. In human toxicology, the absorption, metabolism and excretion of arsenic are well documented. The effect of acute or chronic intoxication depends on sex, age, dose and exposure time (Fowler 1977). In areas with a higher arsenic exposure, consistently elevated concentrations of arsenic in the fur of hares and children's hair were found (Nováková 1973), similarly to the results of the monitoring of this element in the fur of the common vole and wood mouse (Obrusník and Paukert 1973). These results are consistent with our findings of arsenic deposition in the fur of the examined hares. 
Monitoring of arsenic concentrations in the organs of hares is not common compared to other elements, especially heavy metals. There are only few studies on the arsenic in animals, such as that by Skrivanko et al. (2008) in Croatia. Their findings are partially comparable with our results. Possible differences in the concentrations can be explained by different levels of contamination of ecosystems by this toxic element.

In the tissues of animals that were diagnosed with malignant neoplastic diseases, arsenic concentrations ranged from 0.010 to $0.040 \mathrm{mg} \cdot \mathrm{kg}^{-1}$ in the liver and from 0.020 to $0.050 \mathrm{mg} \cdot \mathrm{kg}^{-1}$ in the kidneys, which is comparable with the concentration of the element in the tumour tissue itself $\left(0.02-0.04 \mathrm{mg} \cdot \mathrm{kg}^{-1}\right)$. In a benign tumour, concentrations in the liver were higher than in the tumour tissue; concentrations in the kidneys and the neoplastic tissue were comparable (Bukovjan and Karpenko 1996).

Similar results were found in the examination of organs and other tissues, and in an ovarian malignant tumour of a European badger. The concentration of arsenic was $0.07 \mathrm{mg} \cdot \mathrm{kg}^{-1}$ in the liver, $0.02 \mathrm{mg} \cdot \mathrm{kg}^{-1}$ in the muscle and in the kidney, and $0.03 \mathrm{mg} \cdot \mathrm{kg}^{-1}$ in the tumour (Bukovjan et al. 2014).

Arsenic is a significant toxic element that contaminates the environment including wildlife. Deposition of this element in matrices has a similar character and it only differs in concentrations.

\section{References}

Bukovjan K, Karpenko A 1996: Concentration of chemical elements in tumour of game classified by system. ICD - O (in Czech) Veterinářství 10: 423-425

Bukovjan K, Kutlvašr K, Feureisel J, Ježek M, Havránek F 2011: Auftreten von Tumoren beim Rotfuchs (Vulpes vulpes L.). Beiträge zur Jagd- und Wildforschung 36: 297-300

Bukovjan K, Toman A, Kutlvašr K, Marada P, Kodet R, Sláma P, Křikava L 2014: Contents of chemical elements in tissues of European badger (Meles meles L.) affected by ovarian tumour - A case report. Acta Vet Brno 83: 139-143

Bukovjan K, Wittlingerová Z, Černá E 1997: Chemical elements in tissues and histological changes in tissues of hares (L. europaeus Pall.). Scientia Agriculturae Bohemica 28: 215-226

Dopp E, Hartmann LM, Florea AM, von Recklinghausen U, Pieper R, Shokouhi B, Rettenmeier AW, Hirner AV, Obe G 2004: Uptake of inorganic and organic derivates of arsenic associated with induced cytotoxic and genotoxic effects in Chinese hamster ovary (CHO) cells. Toxicol Appl Pharmacol 201: 156-165

EN 13805:2014: Foodstuffs - Determination of trace elements - Pressure digestion. European Committee for Standardization, 2014

EN 15763:2009: Foodstuffs - Determination of trace elements - Determination of arsenic, cadmium, mercury and lead in foodstuffs by inductively coupled plasma mass spectrometry (ICP-MS) after pressure digestion. European Committee for standardization, 2009.

Fluks JEC 1965: Incidence of ovarian tumors in hares in New Zealand. Journal of Wildlife Management 29: 622-624

Fowler BA 1977: Toxicilogy of Enviromental Arsenic. In: Goyer RA and Mehlman MA (Eds): Toxicology of Trace Elements, Wiley and Sons, New York: 79-122

Germolec DR, Spalding J, Boorman GA, Wilmer JL, Yoshida T, Simeonova PP, Bruccoleri A, Kayama F, Gaido K, Tennant R, Burleson F, Dong W, Lang RW, Luster MI 1997: Arsenic can mediate skin neoplasma by chronic stimulation of keratinocyte-derived growth factors. Mutat Res 386: 209-218

Goering PL, Aposhian HV, Mass MJ, Cebrian M, Beck BD, Waalkes MP 1999: The enigma of arsenic carcinogenesis: role of metabolism. Toxicol Sci 49: 5-14

Hughes MF 2002: Arsenic toxicity and potential action. Toxicol Lett 133: 1-16

Hofe U, Vicente J, Gortazar C 2004: Bilateral ovarian teratoma in a free-living Iberian roe deer (Cervus elaphus hispanicus). New Zeal Vet J 52: 44-45

Hoffmann W, Mörl M 1985: Dermocyste bei einer Hässim. Z Jagdwiss 31: 184-186

Karpenko A, Bukovjan K 1996: Tumours of wildlife animals (In Czech). Česká a Slovenská patologie 32: 78-83

Kutlvašr K, Bukovjan K, Kodet R 2014: Bilateral low grade serous adenocarcinoma of the ovaries in a badger (Meles meles L.) and its assotiation with a borderline serous ovarian tumour: A case report. Vet Med-Czech 59: $44-50$

Mass MJ, Tennant A, Roop BC, Cullen WR, Styblo M, Thomas DJ, Kligerman AD 2001: Methylated trivalent arsenic species are genotoxic. Chem Res Toxicol 14: 355-361

Massányi P, Tataruch F. Slamečka J, Toman R, Jurčík R 2003: Accumulation of lead, cadmium and mercury in liver and kidney of the brown hare (Lepus europaeus) in relation to season, age, and sex in the West Slovakian Lowland. J Environ Sci Heal A 38: 1299-1309 
Myslek P, Kalisinska E 2006: Contents of selected heavy metals in the liver, kidneys and abdominal muscle of the brown hare (Lepus europaeus Pallas 1778) in Central Pomerania, Poland. Pol J Vet Sci 9: 31-41

Nováková E 1973: Influence of industrial immission on cation contents in hare hair. XI. International Congress of Game Biologist, Stockholm: 423-438

Obrusník I, Paukert J 1983: Indication of environmental pollution by means of INAA of the hair of some free living mammals. Journal of Radioanalytical and Nuclear Chemistry, 83: 397-406

Páv J, Márová M 1986: Occurrence of lead, cadmium and mercury in the organs and muscle tissue of hares. (In Czech). Folia Venatoria 18: 151-170

Skrivanko M, Hadziosmanovic M, Ctvrtila Z, Zdolec N, Flipovic I 2008: The hygiene and duality of hare meat (Lepus europaeus Pall.) from Eastern Croatia. Arch Lebensmittelhyg 59: 180-184

Lebersorger P, Zedka F 2009: Hygiene of venison (In Czech). Středoevropský institut ekologie zvěře, Brno-WienNitra, Institut ekologie zvěř VFU Brno, 176 p.

Yanamaka K, Hayashi H, Tachikawa M, Kato K, Hasegawa A, Oku N, Okada S 1997: Metabolic methylation is a possible genotoxicity-enhancing process of inorganic arsenics. Mutat Res Gen Tox En 394: 95-101 